\title{
PENGEMBANGAN KARAKTER MULTIKULTURAL MAHASISWA DALAM PEMBELAJARAN CIVIC EDUCATION \\ (Studi Pada Mahasiswa Jurusan KPI Fakultas Dakwah IAIN Salatiga)
}

\author{
Rasimin \\ Dosen Pengembangan Masyarakat Islam IAIN Salatiga \\ rasimin75@gmail.com
}

\begin{abstract}
Multicultural was resulted from the effect of intersection of individual right among society or civil right in state. Multicultural as the base essence is able to resist the violence existence. This research used Research and Development ( $R \& D)$ method. This research showed that: (a) the modernization progress in Salatiga influenced the shifting of social life in the students' social environment. (b) Communication and Broadcasting of Islam Department (KPI) of Dakwah Faculty positively appreciated model of multicultural character development in civic education learning because it was regarded as innovative model and appropriate with the environment of social society of students. (c) Model of multicultural character development was effective to develop the awareness of tolerant among students. (d) Lecturers were able to deliver civic education material using this model. (e) The supremacy of this model was in the learning objective, affective aspect became the main target, while cognitive and psychomotor aspect became proponent factor.
\end{abstract}

Keywords: Character, Multicultural, Civic Education

\begin{abstract}
Abstrak
Multikultural merupakan bentuk sikap persinggungan hak individu dalam masyarakat. Multikultural sebagai ukuran esensial yang mampu meminimalisisr terjadinya kekerasan. Penelitian menggunakan pendekatan Research and Development (R\&D). Hasil penelitian menujukan bahwa: (a) Kemajuan kota Salatiga terhadap modernisasi yang mempengaruhi pada bergesernya kehidupan bermasyarakat di lingkungan sosial mahasiswa. (b) Jurusan KPI Fakultas Dakwah menyambut positif model pengembangan karakter multikultural dalam pembelajaran civic education karena dianggap inovatif. (c) Model pengembangan karakter multikultural efektif meningkatkan kesadaran bertoleransi mahasiswa. (d) Dosen memiliki kompetensi untuk dapat menyampaikan materi kuliah civic education menggunakan model pengembangan karakter multikultural. (e) Keunggulan model ini terletak pada tujuan pembelajaran, aspek afektif menjadi target utama sementara aspek kognitif dan aspek psikomotor menjadi faktor pendukung.
\end{abstract}

Kata Kunci: Karakter, Multikultural, Civic Education

\section{Pendahuluan}

Masyarakat Indonesia yang dikenal dengan plural akan mudah mengalami gejolak dis-itegrasi bila tidak ada kesepahaman nilai-nilai multikultur, salah satu contohnya adalah banyaknya kerusuhan dan bentrokan antar warga di tengah gejolak masyarakat, jika tidak ada solusi pencegahan akan berdampak pada bahayanya nilai-nilai kesatuan dan keutuhan bangsa serta tegaknya NKRI. Kenyataan ini dapat dilihat dari kondisi sosio-kultural maupun geografis yang begitu beragam dan luas (Aly, 2003:73; 
Inject, Interdisciplinary Journal of Communication, Vol. 1, No. 2, Desember 2016:145-164

Supardan, 2002: 21). Diakui atau tidak keragaman tersebut dapat menimbulkan berbagai persoalan, seperti kemiskinan, kekerasan, perusakan lingkungan, korupsi, kolusi, nepotisme, separatisme, dan hilangnya rasa kemanusiaan, merupakan bentuk nyata dari multikultur tersebut. Wajah multikultur di Indonesia hingga saat ini ibarat api dalam sekam, yang suatu saat bisa mengakibatkan terjadinya berbagai konflik akibat suhu yang memanas. Tentu penyebab konflik banyak sekali, tetapi kebanyakan disebabkan oleh perbedaan kemiskinan, politik, suku, agama, ras, etnis dan budaya.

Kondisi tersebut memerlukan strategi khusus untuk memecahkan berbagai konflik yang terjadi selama ini. Salah satunya adalah dengan pendidikan multikultural. Tawaran ini merupakan konsep pendidikan dengan pemanfaatan keragaman etnis, budaya, bahasa, agama, status sosial, gender, kemampuan, serta umur yang ada di masyarakat. Pada pendidikan multikultural, seorang pendidik tidak hanya dituntut mengajarkan materi saja, tetapi juga harus mampu menanamkan nilai-nilai multikultural kepada peserta didik. Nilai-nilai tersebut adalah nilai demokrasi, nilai humanis, dan nilai keragaman inklusif, sehingga out-put yang dihasilkan memiliki kemampuan dalam menerapkan nilai-nilai itu dalam kehidupan masyarakat. Penyebab konflik yang terjadi akhir-akhir ini, tidak lain adalah pandangan masyarakat yang bersifat eksklusif. Oleh sebab itu untuk mencegah berkembangnya pandangan tersebut, diperlukan adanya pandangan masyarakat yang bersifat inklusif-pluralis, multikultural-humanis, dan dialogis-persuasif.

\section{Permasalahan}

Fokus permasalahan penelitian sebagai berikut: (1) Desain pengembangan karakter multikultural seperti apakah yang efektif dalam pembelajaran Civic Education pada mahasiswa Jurusan KPI Fakultas Dakwah di IAIN Salatiga? (2) Apakah model pengembangan karakter multikultural yang dikembangkan dapat meningkatkan kesadaran bertoleransi pada mahasiswa Jurusan KPI Fakultas Dakwah di IAIN Salatiga? (3) Seberapa tinggi efektivitas pengembangan karakter multikultural dalam pembelajaran civic education pada mahasiswa Jurusan KPI Fakultas Dakwah di IAIN Salatiga?

\section{Membangun Keharmonisan Masyarakat}

Pendidikan memiliki peranan penting dalam memberikan pemahaman kepada masyarakat bahwa negara Indonesia adalah negara yang dikenal sebagai negara 
Rasimin, Pengembangan Karakter Multikultural Mahasiswa Dalam...

majemuk. Unsur-unsur yang membentuk bangsa dan negara Indonesia menurut Budimansyah (2008:26-50) adalah suku bangsa, kepulauan, kebudayaan, golongan, dan agama. Persatuan bangsa dan wilayah negara Indonesia digambarkan dalam lambang negara Garuda Pancasila dengan semboyan Bhinneka Tunggal Ika.

Bhinneka Tunggal Ika sebagai pemersatu Bangsa Indonesia. Bangsa Indonesia yang multi etnik memiliki potensi kerawanan sosial yang berlatar belakang SARA. Nenek moyang telah memberikan warisan luhur yang ada pada nilai-nilai yang terkandung di dalam spirit Bhinneka Tunggal Ika dan Pancasila. Spirit Bhinneka Tunggal Ika dan dasar negara Pancasila yang digali dari nilai-nilai budaya nasional telah membuktikan menjadi alat pemersatu yang handal bagi bangsa Indonesia sampai saat ini. Oleh sebab itu, berbagai isu disintegrasi bangsa yang dipicu sikap inmultikultural yang terjadi akhir-akhir ini perlu upaya pencarian solusi yang bijaksana. Salah satu cara yang dilakukan adalah revitalisasi multikultur yang ada di berbagai daerah guna mengembangkan sikap semangat Bhinneka Tunggal Ika.

Membangun keharmonisan melalui multikultural, berkaitan dengan tugas pendidikan adalah untuk mencerdaskan kehidupan bangsa, menurut Swasono (2012:5-6) memiliki konsepsi dan makna budaya dan bukan konsepsi biologis-genetika semata. Dalam konsepsi seperti ini mencerdaskan kehidupan bangsa bukanlah hanya bermakna mencerdaskan otak intelektual bangsa. Dari konsepsi tersebut di atas jelaslah bahwa mencerdaskan kehidupan bangsa sebenarnya tidak bisa dilepaskan dari konsep nation and character building, yaitu membangun karakter dan peradaban kehidupan bangsa. Mambangun karakter kehidupan berbangsa jelas terkait dengan nilai-nilai Pancasila sebagai jiwa dan kepribadian bangsa Indonesia.

\section{Karakter Multikultural}

Karakter yang baik menurut Lickona (2013:70-72) adalah sesuatu yang kita inginkan bagi anak-anak kita. Karakter yang baik adalah hidup dengan tingkah laku yang benar yakni tingkah laku benar dalam hal berhubungan dengan orang lain (seperti kedermawanan dan rasa simpati) dan berhubungan dengan diri sendiri (misalnya kontrol diri dan tidak berlebih-lebihan). Karakter dalam perspektif pendidikan nilai, menurut Lickona terdiri atas nilai-nilai operatif, nilai-nilai yang berfungsi dalam praktik. Karakter mengalami pertumbuhan yang membuat suatu nilai menjadi budi pekerti, sebuah watak 
Inject, Interdisciplinary Journal of Communication, Vol. 1, No. 2, Desember 2016:145-164

batin yang dapat diandalkan dan digunakan untuk merespon berbagai situasi dengan cara yang bermoral.

Karakter terbentuk dari tiga macam bagian yang saling berkaitan: pengetahuan moral, perasaan moral, dan perilaku moral. Karakter yang baik terdiri atas mengetahui kebaikan, menginginkan kebaikan, dan melakukan kebaikan-kebiasaan pikiran, kebiasaan hati, kebiasaan perbuatan. Ketiganya penting untuk menjalankan hidup yang bermoral; ketiganya adalah faktor pembentuk kematangan moral. Ketika berpikir tentang jenis karakter yang diinginkan bagi anak-anak, jelas bahwa dosen ingin agar mereka mampu menilai hal yang baik dan buruk, sangat peduli pada hal yang benar, dan melakukan apa yang menurut mereka benar bahkan di saat mereka dihadapkan pada tekanan dari luar dan godaan dari dalam.

Untuk membentuk karakter yang baik, ada dua kebajikan fundamental yang dibutuhkan yaitu rasa hormat atau respect dan tanggung jawab atau responsibility. Kebajikan itu merupakan nilai moral fundamental yang harus diajarkan dalam pendidikan karakter (Lickona, 1991:43-45). Selain dua kebajikan fundamental itu, ada sepuluh kebajikan esensial yang dibutuhkan untuk membentuk karakter yang baik. Berdasarkan pendapat Lickona (2004:7-11) kesepuluh kebajikan esensial itu adalah: kebijaksanaan (wisdom), keadilan (justice), ketabahan (fortitude), pengendalian-diri (selfcontrol), kasih (love), sikap positif (positive attitude), kerja keras (hard work), integritas (integrity), penuh syukur (gratitude), dan kerendahan hati (humility).

Pendidikan karakter adalah segala sesuatu yang dilakukan dosen, yang mampu mempengaruhi karakter peserta didik. Hal ini mencakup keteladanan bagaimana perilaku dosen, cara dosen berbicara atau menyampaikan materi, bagaimana dosen bermultikulturalsi, dan berbagai hal terkait lainnya. Menurut T. Ramli, pendidikan karakter memiliki esensi dan makna yang sama dengan pendidikan moral dan pendidikan akhlak. Tujuannya adalah membentuk pribadi mahasiswa, supaya menjadi manusia yang baik, warga masyarakat, dan warga negara yang baik. Adapun kriteria manusia yang baik, warga masyarakat yang baik, dan warga negara yang baik bagi suatu masyarakat atau bangsa, secara umum adalah nilai-nilai sosial tertentu, yang banyak dipengaruhi oleh budaya masyarakat dan bangsanya (Sedyawati, 1986: 25).

Multikultural sesungguhnya berkembang dalam kerangka adanya keberagaman dalam berbagai dimensi kehidupan, sehingga akan dapat terwujud keserasian dan keharmonisan hidup, jauh dari konflik-konflik dan ketegangan-ketegangan sosial, lebih- 
Rasimin, Pengembangan Karakter Multikultural Mahasiswa Dalam...

lebih lagi pertentangan dan permusuhan antar sesamanya dalam masyarakat (Endaswara, 2010:89). Menurut Rahmatullah (2011), multikultural dalam bahasa Arab disebut tasamuh yang berarti suatu sikap menerima pihak lain dan menghargai perbedaan. Jakarimba (2011: on line), berpendapat bahwa multikultural adalah sebuah bentuk sikap akibat adanya persinggungan hak-hak individu di dalam masyarakat atau hak-hak masyarakat dalam negara. Jadi dapat dikatakan bahwa multikulturalsi adalah sebuah solusi bagi adanya perbenturan hak-hak. Multikultural dalam kehidupan bermasyarakat berbangsa dan bernegara terdapat empat makna, yaitu: a) merasa senasib sepenanggungan; b) menciptakan persatuan dan kesatuan, rasa kebangsaan atau nasionalisme; c) mengakui dan menghargai hak asasi manusia; dan d) tidak menjelekjelekan kebudayaan, suku, adat istiadat orang lain.

\section{Metode Penelitian}

Penelitian ini dilakukan dengan tujuan ingin menemukan pengembangan karakter multikultural mahasiswa dalam pembelajaran Civic Education sebagai upaya menanamkan sikap multikulturalsi dalam hidup bermasyarakat, berbangsa dan bernegara bagi mahasiswa Komunikasi dan Penyiaran Islam (KPI) Fakultas Dakwah di IAIN Salatiga. Metode yang digunakan dalam penelitian ini menggunakan pendekatan Research and Development $(R \& D)$. Prosedur Penelitian dilaksanakan melalui dua tahapan, yaitu tahap pendahuluan dan tahap pengembangan. Pada tahap pendahuluan dapat dikatakan sebagai tahap research yang dimulai dari studi lapangan dan studi literatur, perancangan model, dan diakhiri dengan uji model melalui PTK, sementara tahap development dilaksanakan melalui uji kerterapan model secara terbatas.

\section{Hasil Penelitian dan Pembahasan}

Hasil studi pendahuluan menemukan bagaimana gambaran lingkungan sosial masyarakat mahasiswa Jurusan KPI Fakultas Dakwah di IAIN Salatiga menyangkut isu multikultural sehingga dapat dirumuskan suatu solusi bagaimana membangun keharmonisan hidup bermasyarakat berbangsa dan bernegara melalui pembelajaran civic education di Jurusan KPI Fakultas Dakwah. Ada tiga aspek kegiatan studi pada tahap studi pendahuluan, yaitu studi literatur, studi dokumen pembelajaran, dan studi lapangan terkait proses pembelajaran civic education. 
Inject, Interdisciplinary Journal of Communication, Vol. 1, No. 2, Desember 2016:145-164

Tahap studi dokumen dilakukan telah mendapatkan gambaran bagaimana para dosen Jurusan KPI Fakultas Dakwah IAIN Salatiga mempersiapkan pembelajaran civic education dalam bentuk SAP dan bagaimana pelaksanaannya dalam PBM guna mengetahui realitas yang ada. Kenyataan menunjukkan, bahwa ada indikasi para dosen masih mengedepankan ranah kognitif dan psikomotor dalam menyampaikan materi pembelajaran. Hasil studi lapangan terkait proses belajar mengajar oleh dosen di kelas menunjukkan bahwa para dosen masih terkesan sebagai instruktur (berpusat pada dosen sentris). Dominasi dosen dalam proses pembelajaran terasa masih kuat, khususnya dalam merespon jawaban mahasiswa masih mendasarkan pada buku pegangan sehingga kurang memungkinkan pengembangan kreatifitas berpikir mahasiswa.

Kenyataan lainnya, dari hasil studi lapangan menunjukkan bahwa para dosen merasa kesulitan bagaimana mengembangkan materi pembelajaran dengan bersumber pada Civic Education. Kesulitan dosen mengembangkan materi pembelajaran Civic Education kemungkinan disebabkan oleh kebiasaan dosen memahami buku selama ini difahami secara tekstual saja, atau kurang memberi makna secara aktual.

Tahap pengembangan guna perancangan model (hipotetik) didasarkan pada hasil studi literatur, studi dokumen pembelajaran, dan hasil studi lapangan. Hasilnya antara lain: (1) Sikap multikultural perlu ditekankan dalam pembelajaran Civic Education kepada mahamahasiswa karena fenomena yang berkembang di masyarakat akhir-akhir ini sungguh mengkhawatirkan pada keutuhan hidup bermasyarakat berbangsa dan bernegara Indonesia khususnya di Kota Salatiga; dan (2) Masyarakat Salatiga sebenarnya memiliki multikultural seperti sikap guyub-rukun guna dapat dijadikan pedoman hidup bermasyarakat berbangsa dan bernegara Indonesia secara harmonis dan saling menghargai atau saling menghormati.

Model pembelajaran Civic Education bertujuan untuk mengembangkan karater multikultural mahasiswa. Pemilihan materi pembelajaran Civic Education dilandasi oleh filsafat pendidikan perenialisme. Metode diskusi dan bermain peran dijadikan sebagai metode pembelajaran guna mengembangkan keterampilan berpikir (aspek psikomotor) dan guna mengembangkan sikap multikulturalsi (aspek afektif) mahasiswa dalam tataran praktis, sehingga dapat dievaluasi melalui pengamatan langsung oleh dosen evaluasi hasil belajar (evaluasi produk) dalam bentuk tes formatif ditekankan untuk mengetahui tingkat pemahaman mahasiswa (aspek kognitif) terkait kesadaran bersikap multikultural. 
Rasimin, Pengembangan Karakter Multikultural Mahasiswa Dalam...

\section{Gambar 1}

Alur Pengembangan Karakter Multikultural dalam

Pembelajaran Civic Education

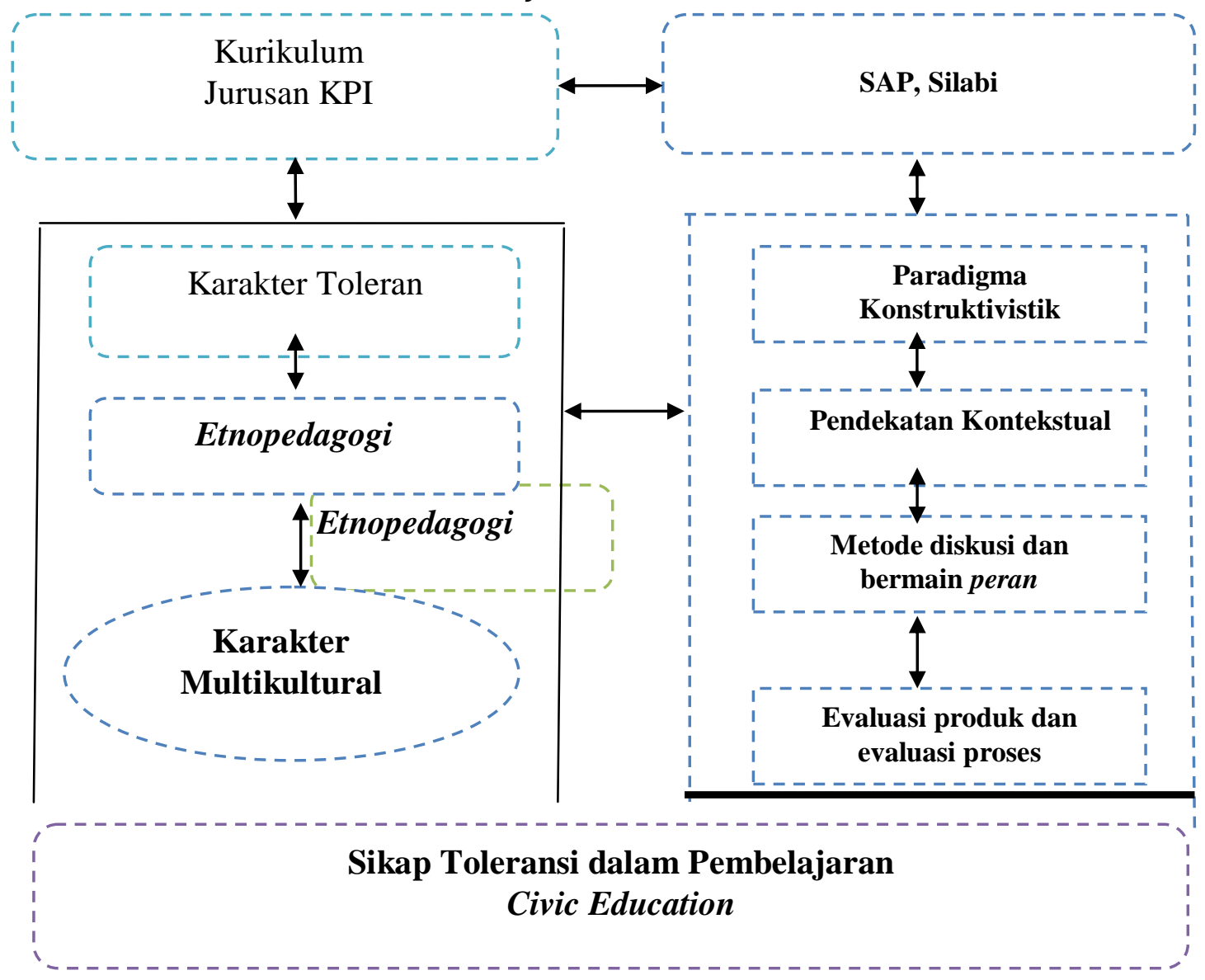

\section{Uji Model Hipotetik Pengembangan Karakter}

a. Uji Model Hipotetik Melalui Action Research

Telah diuraikan pada tahap pendahuluan ditemukan bahwa para dosen di Fakultas Dakwah yang menjadi responden penelitian ini pada umumnya belum pernah melaksanakan pembelajaran civic education melalui pendekatan kontekstual. Para dosen bersifat terbuka dan memberikan respon positif terhadap informasi terkini menyangkut dinamisasi akademis yang cukup inovatif guna meningkatkan kemampuan professional dalam bidang pengajaran. Termasuk dosen mitra PTK ini, dengan cepat merespon dan menyesuaikan pembelajaran seperti yang diinginkan sesuai dengan tujuan penelitian ini. Melalui diskusi yang intens dimulai dari tahap persiapan dan bagaimana penerapan strategi pembelajarannya, akhirnya proses pembelajaran dapat dilaksanakan. Dosen mitra PTK mengalami kemajuan cukup menggembirakan sehingga pada siklus ke tiga 
Inject, Interdisciplinary Journal of Communication, Vol. 1, No. 2, Desember 2016:145-164

bisa dikatakan model pembelajaran civic education yang disampaikan berhasil baik seperti harapan penelitian.

b. Efektivitas Model, hipotetik melalui Uji Keterterapan

Efektifitas model, hipotetik dilakukan melalui uji keterterapan setelah model (hipotetik) ditentukan melalui uji model dilaksanakan menggunakan penelitian action research dengan pendekatan kualitatif. Uji keterterapan model digunakan untuk mengetahui efektifitas model dengan pendekatan kuantitatif. Model divalidasi melalui dua tahap pada 2 kelas eksperimen dan melibatkan 2 kelas kontrol sebagai pembanding pada jurusan yang terlibat penelitian. Pada uji keterterapan tahap I menggunakan 1 kelas eksperimen dan 1 kelas kontrol (Kelas A dan B) pada Jurusan Komunikasi dan Penyiaran Islam (KPI) Fakultas Dakwah. Selanjutnya pada uji keterterapan tahap II menggunakan 1 kelas eksperimen dan 1 kelas kontrol. Pada 1 kelas eksperimen dan 1 kelas kontrol (Kelas C dan D) dilaksanakan di Jurusan Komunikasi dan Penyiaran Islam (KPI).

Sebelum uji keterterapan model (hipotetik) dilaksanakan, dengan dibantu oleh dosen mitra PTK melakukan diseminasi kepada para dosen dan supervisor (ketua jurusan) yang terlibat penelitian. Diseminasi dilakukan agar para dosen mitra khususnya dosen kelas eksperimen dapat melaksanakan pembelajaran sesuai dengan tujuan penelitian. Pada saat diseminasi ini, dosen mitra diberi instrument berupa perangkat pembelajaran antara lain SAP, materi pembelajaran, media pembelajaran, materi diskusi, naskah bermain peran, dan soal tes formatif. Demikian pula, supervisor sebagai validator membantu melaksanakan evaluasi kepada dosen mitra eksperimen berdasarkan instrument yang telah disiapkan oleh peneliti.

Instrument untuk validator dan dosen berwujud pertanyaan tertutup dan pertanyaan terbuka. Untuk mengetahui bagaimana model pembelajaran yang dikembangkan mendapatkan respon mahasiswa selama proses pembelajaran maka digunakan instrument untuk mahasiswa. Semua pertanyaan dalam instrumen untuk mahasiswa berupa pertanyaan tertutup.

\section{c. Uji Keterterapan Model Secara Terbatas}

Pelaksanaan uji keterterapan tahap I dilaksanakan di kelas A sebagai kelas control. Pada kelas A ini diasumsikan dapat mewakili uji keterterapan model yang selanjutnya akan dikembangkan untuk uji keterterapan model tahap II pada kelas C. 
Rasimin, Pengembangan Karakter Multikultural Mahasiswa Dalam...

Tabel 1: Data jumlah mahasiswa Jurusan KPI

Kode Kelas

Jumlah mahasiswa

Ket

\begin{tabular}{ccc}
\cline { 2 - 3 } & Kontrol & Eksperimen \\
$\mathrm{A}$ & 35 & 36 \\
\hline $\mathrm{B}$ & 39 & 26 \\
\hline $\mathrm{C}$ & 34 & 30 \\
\hline $\mathrm{D}$ & 32 & 33 \\
\hline
\end{tabular}

Dari data pada tabel di atas dapat diketahui bahwa rata-rata jumlah mahasiswa di Juruasan KPI ada 30 mahasiswa pada setiap kelas dari 8 kelas yang terlibat penelitian. Hasil uji keterterapan model pembelajaran yang mewakili jurusan KPI seperti tampak pada tabel di bawah ini.

Tabel 2: Rata-rata hasil belajar pada Jurusan KPI

\begin{tabular}{lcccccc} 
Kode & \multicolumn{2}{c}{ Nilai Pretest } & \multicolumn{2}{c}{ Nilai Posttest } & \multicolumn{2}{c}{ Rata-rata Kenaikan } \\
\cline { 2 - 7 } Kelas & $\begin{array}{c}\text { Kontr } \\
\text { ol }\end{array}$ & $\begin{array}{c}\text { Ekspm } \\
\text { en }\end{array}$ & Kontrol & $\begin{array}{c}\text { Eksperime } \\
\text { n }\end{array}$ & $\begin{array}{c}\text { Kontr } \\
\text { ol }\end{array}$ & $\begin{array}{c}\text { Eksperi } \\
\text { men }\end{array}$ \\
\hline A & 61 & 66.22 & 80.05 & 82.39 & 19.05 & 16.17 \\
\hline B & 50.36 & 51.42 & 59.08 & 89.27 & 8.72 & 37.85 \\
\hline C & 50.36 & 51.42 & 59.08 & 89.27 & 8.72 & 37.85 \\
\hline D & 61 & 66.22 & 80.05 & 82.39 & 19.05 & 16.17
\end{tabular}

Dari data yang ditampilkan pada tabel di atas dapat diperinci dan digambarkan dalam bentuk diagram seperti di bawah ini.

Diagram 1: Perbandingan hasil nilai rata-rata pre-test

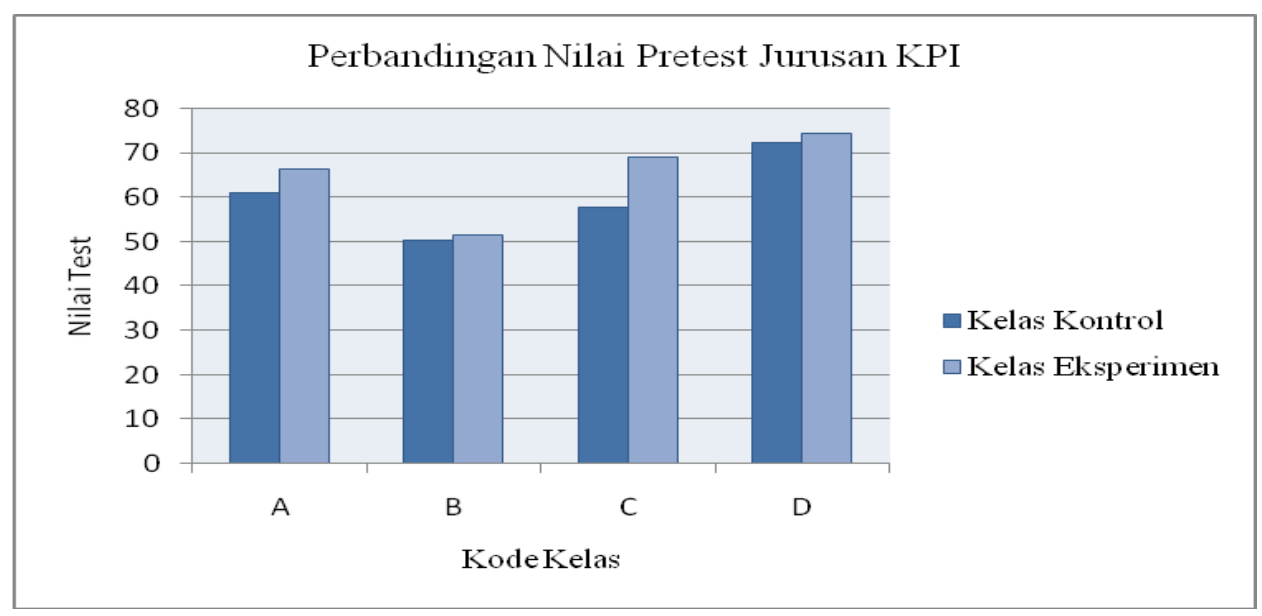


Diagram 2: Perbadingan Hasil Rata-Rata Nilai Post-Test

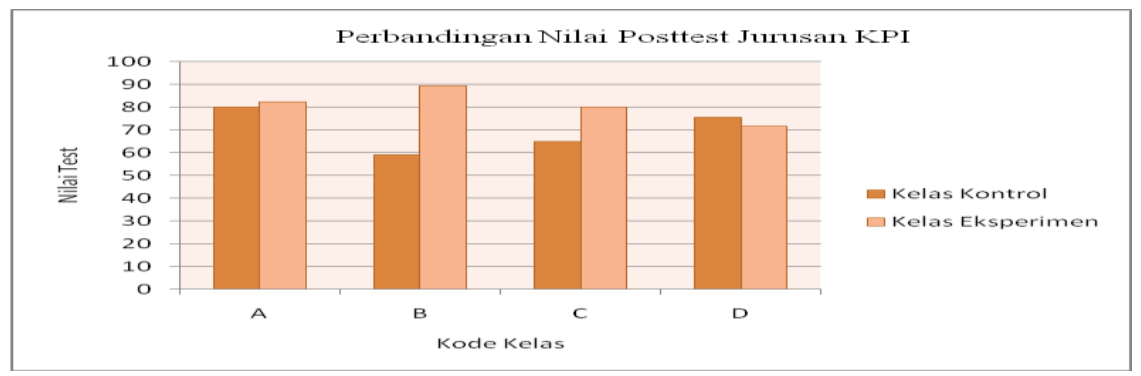

Diagram 3: Perbandingan Rata-Rata Kenaikan Hasil Belajar

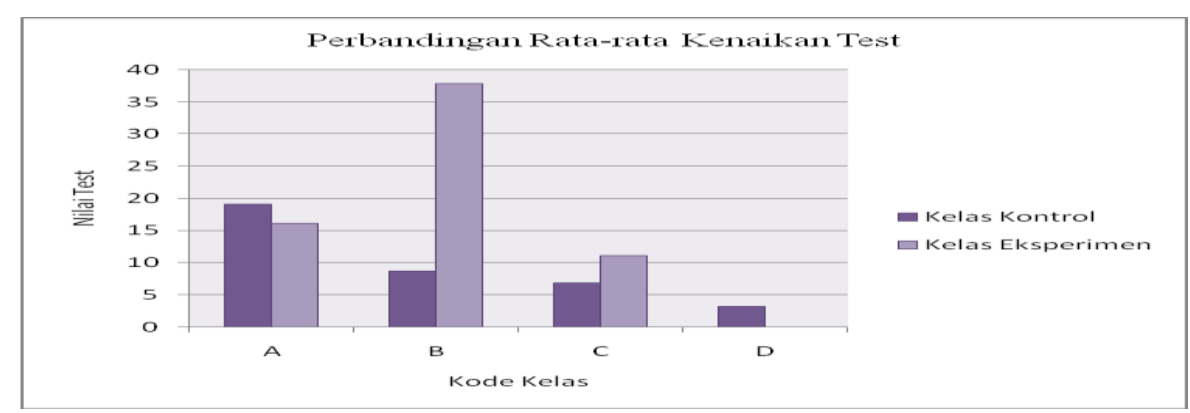

Dari tabel dan diagram di atas tampak bahwa pada kelas kontrol nilai pre-tes ratarata berada di bawah kelas eksperimen (kontrol < eksperimen). Perbedaan tersebut tidak begitu tajam, kecuali pada kelas A sebagai kelas kontrol dan kelas B sebagai kelas eksperimen $(57.81<64,71)$. Perbedaan cukup tajam pada kelas $\mathrm{C}$ ini dimungkinkan dan bisa diterima karena SDM mahasiswa pada kedua kelas ini memiliki kualifikasi yang relatif berbeda pula dari latar belakang mahasiswa berasal. Hal ini dikuatkan dengan kenaikan rata-rata prestasi belajar mahasiswa kedua kelas tersebut pada saat post-tes, di mana pada kelas A sebagai kelas kontrol tetap lebih rendah dari kelas B sebagai kelas eksperimen yaitu pada kelas kontrol kenaikan rata-rata 6,9 lebih rendah dari kelas eksperimen dengan kenaikan rata-rata 11,14 atau $(6,9<11,14)$. Secara keseluruhan dari jumlah mahasiswa pada 4 kelas yang terlibat penelitian tidak memiliki perbedaan yang berarti dari hasil pre-tes yang dilaksanakan. Apabila nilai rata-rata pre-tes pada kelas kontrol dan kelas eksperimen tidak memiliki perbedaan yang cukup berarti, maka 4kelas ini bisa dianggap pantas untuk pelaksanaan uji keterterapan model pembelajaran.

Untuk kenaikan nilai rata-rata post-tes pada kelas kontrol dan kelas eksperimen pada umumnya mengalami kenaikan kecuali pada kelas eksperimen (Kelas B, dan D). Pada kelas eksperimen tersebut nilai pre-tes $(74,29)$ lebih baik hasilnya daripada nilai post-tes $(71,62)$ atau $(74,29>71,62)$ sehingga dapat dikatakan pada kelas eksperimen D 
Rasimin, Pengembangan Karakter Multikultural Mahasiswa Dalam...

kenaikannya 0 . Namun demikian hasil belajar pada kelas eksperimen D ini masih dalam kategori baik karena hasilnya di atas standart keberhasilan belajar yaitu di atas 70 . Artinya, walaupun ada satu kelas eksperimen yang menurun prestasi belajarnya, tetapi rata-rata secara keseluruhan prestasi hasil belajar mahasiswa pada kelas kontrol berada di bawah hasil belajar pada kelas eksperimen. Dapat dimaknai, bahwa kelas eksperimen telah membuktikan keberhasilannya melaksanakan model pembelajaran civic education ditunjukkan melalui nilai rata-rata hasil belajar pada nilai post-tes lebih tinggi daripada nilai pre-tes.

Pada diagram di atas, menggambarkan perbedaan tingkat kenaikan masing-masing pada kelas kontrol dan kelas eksperimen. Tampak jelas bahwa dari emapat kelas yang terlibat penelitian semua menunjukkan kenaikan prestasi hasil belajar, kecuali pada 1 kelas (kelas eksperimen D) seperti telah dijelaskan di atas. Maknanya, tidak semua dosen pada kelas eksperimen mampu melaksanakan proses pembelajaran dengan menggunakan model pembelajaran sesuai harapan penelitian atau tidak semua mahasiswa pada kelas eksperimen dapat menerima model pembelajaran yang telah disampaikan oleh dosen atau dapat juga diartikan model pembelajaran dapat dilaksanakan secara optimal oleh dosen tetapi para mahasiswa tidak bisa memperoleh hasil belajar maksimal. Pernyataan ini akan tampak pada penjelasan pada sub bab selanjutnya, terkait penilaian oleh validator terhadap dosen saat melaksanakan model pembelajaran dan bagaimana dosen menilai perangkat pembalajaran. Bahwa, satu atau dua dosen dalam komponen pembelajaran tertentu kurang bisa maksimal dapat melaksanakan dan ada satu atau dua dosen menilai pada perangkat pembelajaran yang telah disiapkan peneliti dianggap biasa saja (kurang bermakna bagi dosen).

Dari uraian di atas dapat memberikan arti bahwa, (1) Hasil rata-rata prestasi belajar mahasiswa pada kelas eksperimen lebih baik daripada rata-rata prestasi hasil belajar mahasiswa kelas control; (2) Model pembelajaran dapat meningkatkan prestasi hasil belajar secara lebih efektif dibandingkan dengan kelas kontrol. Perbedaan banyak sedikitnya jumlah mahasiswa tidak memiliki pengaruh terhadap hasil pembelajaran menggunakan model yang dikembangkan, hal ini tampak jelas bahwa pada jumlah mahasiswa yang sedikit hasil belajarnya paling tinggi atau mahasiswa yang banyak hasil belajarnya paling rendah atau sebaliknya. Dari table diatas dapat diketahui, bahwa kelas eksperimen B kenaikan prestasi hasil belajarnya tertinggi $(37,85)$ dengan jumlah 26 mahasiswa. Berturut-turut kenaikan prestasi berada dibawahnya, yaitu kelas eksperimen 
A $(16,17)$ dengan jumlah 36 mahasiswa; kelas eksperimen C $(11,14)$ dengan jumlah 35 mahasiswa; dan terendah pencapaian kenaikan hasil belajar yaitu kelas $D$ ( $0 /$ tidak mengalami kenaikan) dengan jumlah 34 mahasiswa. Dapat dimaknai, tidak semua dosen pada kelas eksperimen mampu melaksanakan proses pembelajaran dengan menggunakan model pembelajaran sesuai harapan penelitian, atau tidak semua mahasiswa pada kelas eksperimen dapat menerima model pembelajaran yang telah disampaikan oleh dosen, atau dapat juga dimaknai bahwa model pembelajaran dapat dilaksanakan secara optimal oleh dosen tetapi para mahasiswa tidak bisa memperoleh hasil belajar maksimal. Hasil nilai rata-rata pre-tes yang tinggi tidak serta merta berdampak langsung pada tingginya pencapaian rata-rata nilai post-tes. Misalnya, tampak pada kelas eksperimen B nilai ratarata pre-tes terendah $(51,42)$ tetapi nilai rata-rata post-tes tertinggi $(89,27)$ dibanding kelas yang lain.

Sementara, pada kelas eksperimen D nilai rata-rata pre-tes tertinggi $(74,29)$ tetapi tidak mengalami kenaikan hasil belajar pada saat dilaksanakan post-tes malahan mengalami penurunan menjadi $(71,62)$. Menurunya nilai post-tes dibanding pre-tes pada kelas eksperimen $\mathrm{D}$ ini dipengaruhi dosen pada kelas eksperimen $\mathrm{D}$ tidak mengikuti diseminasi. Seingat peneliti, dosen kelas eksperimen D tidak mengikuti diseminasi karena datang terlambat dengan alasan sedang menyelesaikan tugas di sekolah. Dosen datang saat acara baru saja ditutup sehingga hanya sempat menerima semua perangkat pembelajaran dan hanya menerima arahan secara garis besar saja, bagaimana teknis pelaksanaan dengan perangkat pembelajaran yang ada. Dimungkinkan, para mahasiswa tidak memahami apa yang diterangkan dosen, justru semakin bingung dengan apa yang dijelaskan dosen kelas eksperimen $\mathrm{D}$ ini. Kebingungan mahasiswa bisa difahami, karena dosen dalam menyampaikan materi pembelajaran (kemungkinan) tidak mengikuti prosedur apa yang seharusnya dilakukan dengan model yang dikembangkan. Hal ini dibuktikan oleh hasil jawaban (respon) dari instrument yang diberikan kepada mahasiswa di daerah urban.

Di kelas kontrol ada 34 mahasiswa dari 4 kelas eksperimen yang menjadi responden terkait model yang dikembangkan ini. Pada umumnya mahasiswa senang terhadap materi pelajaran yang diberikan dosen yaitu ada 30 mahasiswa $(88,24 \%)$; senang terhadap modul yang digunakan ada 31 mahasiswa $(91,18 \%)$; senang terhadap suasana belajar yang tercipta ada 28 mahasiswa (82,35\%); dan senang terhadap cara dosen mengajar ada 28 mahasiswa (82,35\%). Umumnya mahasiswa menjawab sebagai 
Rasimin, Pengembangan Karakter Multikultural Mahasiswa Dalam...

hal yang baru pada pembelajaran yang disampaikan dosen. Rinciannya yaitu, terhadap materi pelajaran ada 29 mahasiswa (85,40\%); terhadap modul ada 30 mahasiswa $(88,23 \%)$; terhadap suasana belajar di kelas ada 28 (82,35\%); dan cara mengajar dosen ada 28 mahasiswa $(82,35 \%)$ mengatakan baru.

Dapat disimpulkan, bahwa dosen di kelas kontrol (dimungkinkan dosen kelas eksperimen D) mendapat respon (terbesar) dari 6 mahasiswa (17,65\%) yang mengatakan perasaannya tidak senang dengan suasana belajar di kelas dan tidak senang terhadap cara dosen mengajar ada 6 mahasiswa (17,65\%). Demikian pula terhadap suasana belajar ada 6 mahasiswa $(17,65 \%)$ mengatakan tidak baru, terhadap cara mengajar dosen juga ada 6 mahasiswa (17,65\%) mengatakan tidak baru. Penyebab dari jawaban mahasiswa tersebut mengindikasikan bahwa cara dosen menyampaikan pembelajaran masih konfensional walaupun semua perangkat pembelajaran model yang dikembangkan sebagai hal baru. Buktinya, secara umum mahasiswa kelas eksperimen sekolah urban menyatakan senang dengan materi pelajaran (di atas 80\%) pada model yang dikembangkan ini. Cara mengajar masih konfensional dimungkinkan karena dosen kelas eksperimen $\mathrm{D}$ tidak mengikuti diseminasi.

Mahasiswa kelas eksperimen D, cara menjawab soal tes kemungkinan dilakukan dengan menduga saja tanpa melakukan analisis semestinya sehingga jawaban pre-tes lebih baik daripada saat post-tes. Bila dilihat dari pencapaian rata-rata prestasi hasil belajar pada kelas eksperimen lebih baik dibandingkan dengan kelas kontrol maka dapat dikatakan bahwa model pembelajaran ini pada tahap I terbukti efektif dapat meningkatkan prestasi hasil belajar mahasiswa. Efektivitas model pembelajaran telah terbukti dapat dicapai sehingga layak untuk diuji keterterapannya pada tahap II. Karena model pembelajaran terbukti efektif maka tidak diperlukan upaya revisi desain model pembelajaran.

\section{Perbedaan Hasil Belajar Mahasiswa}

Agar lebih jelas dapat mengetahui seberapa besar perbedaan efektifitas model pembelajaran yang dikembangkan, berikut ini akan diuraikan kenaikan rata-rata hasil belajar pada kelas kontrol dan kelas eksperimen. 
Inject, Interdisciplinary Journal of Communication, Vol. 1, No. 2, Desember 2016:145-164

Tabel 3: Kenaikan Hasil Belajar Pada Kelas Kontrol Dan Kelas Eksperimen Kelas Kelas

\begin{tabular}{ccc} 
Kelas & Kontrol & Eksperimen \\
\hline A & 19.05 & 16.17 \\
\hline B & 8.72 & 37.85 \\
\hline C & 6.9 & 11.14 \\
\hline D & 3.23 & 0
\end{tabular}

Diagram 4: Perbandingan Kenaikan Hasil Belajar Pada Kelas Kontrol dan Kelas Eksperimen

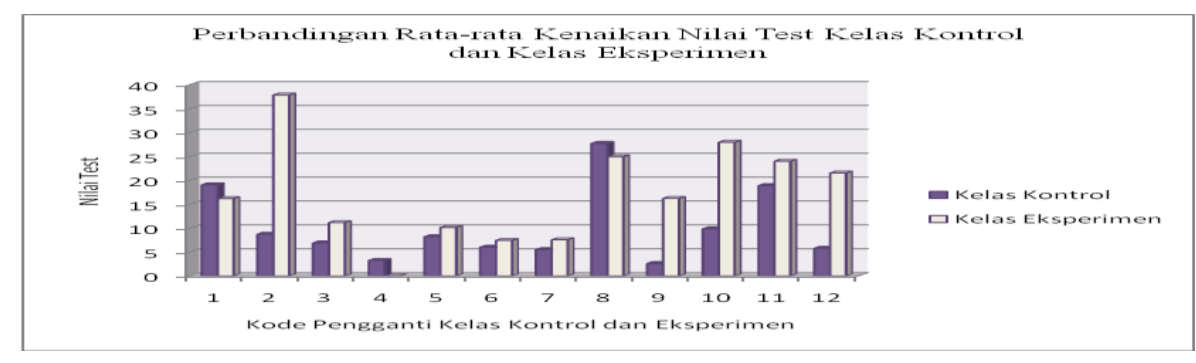

Pada tabel dan gambar diagram di atas, dengan jelas diketahui bahwa pada umumnya pada kelas eksperimen dan kelas kontrol rata-rata mengalami kenaikan nilai post-tes-nya, kecuali pada kelas D eksperimen. Tampak jelas, pada kelas eksperimen D nilai post-tes dapat dikatakan kenaikannya 0 atau tidak ada kenaikan. Bahkan dilihat dari prestasi nilai post-tes mengalami penurunan dibandingkan dengan nilai pre-tes. Namun demikian, secara keseluruhan dari 4 kelas eksperimen kenaikan prestasi nilai post-tes meningkat rata-rata lebih baik atau lebih tinggi daripada kelas kontrol. Hanya pada 3 kelas pada kelas kontrol kenaikannya lebih tinggi daripada kelas eksperimen. Sementara, pada 4 kelas eksperimen kenaikan prestasi pada nilai post-tes mengalami kenaikan cukup signifikan dibandingkan dengan kenaikan nilai post-tes pada kelas kontrol. Artinya: (1) pengembangan karakter multikultural dalam pembelajaran civic education yang dikembangkan dalam penelitian ini terbukti dapat meningkatkan prestasi hasil belajar mahasiswa; (2) Banyak-sedikitnya jumlah mahasiswa tidak berpengaruh langsung pada tinggi-rendahnya kenaikan rata-rata prestasi belajar; dan (3) Dengan pengembangan karakter multikultural, mahasiswa di eksperimen rata-rata hasilnya lebih baik dibandingkan dengan mahasiswa kelas kontrol. 
Rasimin, Pengembangan Karakter Multikultural Mahasiswa Dalam...

Model pembelajaran yang dikembangkan pada umumnya dapat dilaksanakan oleh dosen sesuai dengan harapan penelitian. Hanya ada satu dosen kelas eksperimen menunjukkan tidak dapat melaksanakan dengan baik yaitu ditunjukkan pada rata-rata hasil belajar mahasiswanya (post-test) lebih rendah daripada hasil pre-test (kelas D). Pada umumnya dosen dapat memahami dengan baik model yang dikembangkan untuk dilaksanakan dalam proses pembelajaran. Model pembelajaran yang dikembangkan pada umumnya dapat difahami oleh mahasiswa kelas eksperimen yang terlibat penelitian dengan baik. Memiliki makna, bahwa model pembelajaran civic education melalui pendekatan kontekstual berbasis kearifan lokal Jawa yang dikembangkan dalam penelitian ini berhasil efektif meningkatkan kesadaran bersikap multikulturalsi yang dibuktikan melalui peningkatan prestasi hasil belajar mahasiswa kelas eksperimen yang terlibat penelitian.

Berdasarkan pada temuan, dengan tidak mengurangi arti dari penurunan prestasi hasil belajar di kelas eksperimen $\mathrm{D}$ dapat dimaknai bahwa tidak semua dosen pada kelas eksperimen mampu melaksanakan proses pembelajaran dengan menggunakan model pembelajaran sesuai harapan penelitian, atau tidak semua mahasiswa pada kelas eksperimen dapat menerima model pembelajaran yang telah disampaikan oleh dosen, atau dapat juga dimaknai bahwa model pembelajaran dapat dilaksanakan secara optimal oleh dosen tetapi para mahasiswa tidak bisa memperoleh hasil belajar maksimal. Bisa juga dikatakan, temuan pada kelas eksperimen $\mathrm{D}$ adalah kasus yang terjadi pada penelitian ini karena satu-satunya Jurusan/kelas di mana nilai pre-tes lebih tinggi dibandingkan dengan nilai post-tes (74,29/pre-test $>71,62 /$ post-tes)padahal telah mendapatkan perlakuan dalam proses pembelajaran melalui model yang dikembangkan.

Bahwa pembelajaran civic education guna mengembangkan karakter multikultural mahasiswa pada 4 kelas eksperimen oleh dosen kelas berjalan sesuai dengan harapan penelitian. Dosen merasa terbantu dengan perangkat pembelajaran yang berupa SAP, materi ajar, media pembelajaran, modul diskusi, pedoman bermain peran, dan soal tes hasil belajar. Para dosen civic education telah melaksanakan pembelajaran sesuai dengan SAP dan perangkat pembelajaran yang disiapkan peneliti. Dari 24 komponen keterlaksanaan PBM dengan pengembangan karakter multikultural dalam pembelajaran civic education dapat dijalankan dengan baik. Hal ini dibuktikan dengan hasil pengamatan selama uji validasi keterterapan model oleh para validator (validator) yaitu setiap komponen rata-rata memperoleh nilai 3,94 (kategori di atas cukup atau baik). Demikian 
Inject, Interdisciplinary Journal of Communication, Vol. 1, No. 2, Desember 2016:145-164

pula, keterlaksanaan pengajaran dengan pendekatan induktif yang dinilai melalui 12 indikator oleh para validator (validator) dinyatakan dapat dilaksanakan dengan baik, yaitu mendapat nilai rata-rata 3,89 (kategori di atas cukup atau baik).

Pada kelas eksperimen, prestasi hasil belajar pengembangan karakter multikultural pada pembelajaran civic education hasilnya rata-rata lebih tinggi dibandingkan dengan kelas kontrol. Para mahasiswa merasa senang terhadap materi yang disajikan oleh dosen dan cara mengajar dosen dianggap hal baru oleh para mahasiswa. Pada umumnya para mahasiswa mengatakan bahwa sikap toleransi diperlukan dalam pergaulan hidup seharihari, yaitu ada $(95,45 \%)$ dari seluruh mahasiswa yang dijadikan responden penelitian.

\section{Pengembangan Karakter Multikultural}

Pengembangan karakter multikultural dalam pembelajaran civic education pada penelitian ini berdasar pada pengelompokan model pengajaran the social family. Model pengembangan karakter multikultural pada penelitian ini, bisa ditentukan setelah melalui tiga siklus action pembelajaran di kelas. Hal yang menggembirakan, dosen mitra PTK bersama para mahasiswanya sangat mendudukung penelitian ini. Dengan sungguhsungguh dosen PTK mengikuti semua arahan, koreksi, dan bimbingan dari peneliti untuk melakukan segala upaya agar pelaksanaan pembelajaran dengan pendekatan kontekstual mencapai hasil yang optimal. Demikian pula, para mahasiswa yang terlibat PTK mengikuti pembelajaran dengan penuh semangat, sungguh-sungguh dan tampak senang mengikuti pembelajaran selama tiga sklus. Antusias mahasiswa mengikuti pembelajaran juga tampak pada saat melaksanakan tugas diskusi dan bermain peran.

Respon positif dari dosen mitra PTK dapat dibuktikan dengan menyusun sendiri naskah cerita bermain peran berdasarkan pedoman bermain peran dari peneliti. Berdasarkan persetujuan dosen mitra tersebut, naskah cerita karyanya, oleh peneliti digunakan sebagai materi naskah bermain peran pada tahap uji keterterapan. Pelaksanaan model pengembangan karakter multikultural dalam pembelajaran civic education melalui pendekatan kontekstual dengan metode diskusi dan bermain peran oleh dosen mitra dapat dilaksanakan sesuai harapan penelitian. Dosen mitra tampak telah bisa mengaktifkan mahasiswa selama proses pembelajaran sesuai dengan SAP yang disiapkan peneliti. Penjelasan dosen sebatas pada konsep multikultural, pemberian contoh konflik sosial sebagai stimulus pembelajaran, dan penjelasan teknis bagaimana melaksanakan diskusi dan bermain peran. Bisa dikatakan, kurang lebih 20\% waktu untuk 
Rasimin, Pengembangan Karakter Multikultural Mahasiswa Dalam...

penjelasan oleh dosen dan $80 \%$ waktu lainnya untuk aktivitas mahasiswa selama pembelajaran.

Pembelajaran civic education untuk mengembangkan karakter multikultural menggunakan model konsiderasi dapat dilaksanakan dengan baik. Hal ini ditunjukkan oleh dosen dalam menyajikan materi ajar dan naskah bermain peran guna mengembangkan sikap multikulturalsi untuk bisa hidup harmonis di lingkungan masyarakat tempat tinggal. Dosen juga dapat mengembangkan sikap multikulturalsinya dan menghargai potensi mahasiswa dengan cara menerima pendapat, ide, masukan dari mahasiswa selama mendukung dan memperjelas pemaknaan tujuan pembelajaran. Tidak tampak adanya dominasi, otorisasi, dan egoisme selama proses pembelajaran berlangsung yang dilakukan oleh dosen atau mahasiswa.

Pembelajaran menggunakan pendekatan kontekstual oleh dosen mitra dapat dilihat dari bagaimana dosen menjelaskan materi pembelajaran untuk mengembangkan nilainilai karakter multikultural guna mengembangkan kehidupan harmonis di masyarakat. Tampak, bahwa mahasiswa senang dengan cara dosen menyampaikan pembelajaran. Hal ini dibuktikan oleh mahasiswa selama mengikuti pembelajaran dengan bertanya, menjawab pertanyaan dosen, serius melaksanakan diskusi, dan sungguh-sungguh memainkan perannya dalam bermain peran.

Pertanyaan yang ada pada modul diskusi dapat dijawab dengan baik, karena pada siklus I walaupun belum semua benar tetapi bisa dikatakan $80 \%$ jawaban sudah terjawab benar seperti yang ditanyakan pada modul. Mahasiswa menjawab salah atau tidak tepat sekitar 20\% dikarenakan pertanyaan sulit difahami mahasiswa sehingga pada siklus II dilakukan revisi dengan pertanyaan yang disederhanakan. Pertanyaan pada modul diskusi terjawab dengan benar semua setelah pada siklus III.

Terkait dengan alokasi waktu, pada siklus I memerlukan waktu yang panjang. Oleh sebab itu, penjelasan dosen disederhanakan agar lebih efektif, dan jumlah pertanyaan diskusi di kurangi. Pada pelaksanaan siklus II waktu yang disediakan masih tidak mencukupi sehingga perlu menambah waktu. Setelah dilakukan revisi terkait teknis penjelasan pembelajaran oleh dosen, akhirnya pada siklus III secara keseluruhan perangkat pembelajaran, strategi pendekatan kontekstual, metode diskusi dan bermain peran yang digunakan selama proses pembelajaran dapat disajikan sesuai porsi waktu yang disediakan sesuai harapan. 
Inject, Interdisciplinary Journal of Communication, Vol. 1, No. 2, Desember 2016:145-164

Hasil evaluasi produk pada kelas PTK menunjukkan kenaikan prestasi hasil belajar mahasiswa. Pada saat pre-tes nilai rata-rata mahasiswa 5,76 dan meningkat hasilnya pada saat post-tes dengan rata-rata nilai 8,34 . Sementara, pada hasil diskusi setelah pada siklus ketiga semua mahasiswa dapat menjawab pertanyaan yang ada pada modul dengan benar. Hasil evaluasi proses, ditunjukkan oleh sikap mahasiswa melalui pertanyaan aplikatif kepada dosen dan kepada peniliti (peneliti selalu mengikuti aktivitas pembelajaran pada saat PTK) yang mencerminkan moral mahasiswa yang baik dengan perspektif multikulturalsi yaitu tampak dalam membantu dosen dan teman lain dalam menyiapkan pelaksanaan bermain peran. Peningkatan prestasi hasil belajar sebagai hasil dari evaluasi produk dapat memberikan makna bahwa ada peningkatan kesadaran bermultikulturalsi mahasiswa, sementara hasil evaluasi proses dapat memberikan makna bahwa mahasiswa telah dapat bersikap-perilaku bermultikulturalsi dengan orang lain. Peningkatan hasil belajar baik dilihat dari evaluasi produk maupun evaluasi proses tersebut dapat diartikan bahwa penekanan aspek afektif dalam PBM menggunakan model pengembangan karakter multikultural dalam pembelajaran civic education melalui pendekatan kontekstual berhasil meningkatkan kesadaran bermultikulturalsi mahasiswa. Akhir dari pelaksanaan PTK dapat dinyatakan, bahwa model yang dikembangkan dalam pembelajaran civic education melalui pendekatan kontesktual telah berhasil menemukan model yang diharapkan.

\section{Simpulan}

Dari hasil penelitian tentang pengembangan karakter multikultural mahasiswa dalam pembelajaran civic education di Jurusan KPI Fakultas Dakwah di IAIN Salatiga dapat disimpulkan sebagai berikut: (a) Kemajuan kota Salatiga terhadap modernisasi yang mempengaruhi pada bergesernya kehidupan bermasyarakat di lingkungan sosial mahasiswa. (b) Praksis jurusan KPI Fakultas Dakwah menyambut positif terhadap model pengembangan karakter multikultural dalam pembelajaran civic education karena dianggap inovatif dan sesuai dengan lingkungan sosial masyarakat mahasiswa. (c) Model pengembangan karakter multikultural efektif dapat meningkatkan kesadaran bertoleransi mahasiswa. Hal ini dibuktikan kesadaran toleransi mahasiswa tampak pada sikap yang ditampilkan selama proses belajar mengajar di mana para mahasiswa tidak memaksakan kehendak, menghormati dan menghargai pendapat teman dalam diskusi, ada empati dan dapat bekerja sama dalam bermain peran.

(d) Dosen pada umumnya memiliki 
Rasimin, Pengembangan Karakter Multikultural Mahasiswa Dalam...

kompetensi untuk bisa menyampaikan materi kuliah civic education menggunakan model pengembangan karakter multikultural ini. Hal ini dibuktikan oleh kenaikan prestasi hasil belajar mahasiswa dan suasana kelas yang kondusif menyenangkan bagi mahasiswa selama pembelajaran berlangsung. (e) Kendala yang dihadapi dalam pelaksanaan model pengembangan karakter multikultural dalam pembelajaran civic education ialah para dosen tidak memiliki referensi cukup memadai, kurangnya kreatifitas dalam mengembangkan materi ajar karena tidak terbiasa mengembangkan strategi pembelajaran dengan pendekatan kontekstual. (f) Keunggulan pada model ini ialah pada tujuan pembelajaran, di mana aspek afektif menjadi target utama sementara aspek kognitif dan aspek psikomotor menjadi faktor pendukung pencapaian target pada aspek afektif.

\section{Daftar Pustaka}

Ali, Muhammad. 2010. Dosen Dalam Proses Belajar Mengajar. Bandung: Sinar Baru Algensindo.

Alwasilah, A. Chaedar, dkk. 2009. Etnopedagogi Landasan Praktek Pendidikan dan Pendidikan Dosen. Bandung: PT Kiblat Buku Utama.

Anderson, Lorin W, \& David R. Krathwohl. 2010. Kerangka Landasan untuk Pembelajaran, Pengajaran, dan Asesmen(Terjemahan). Yogyakarta: Pustaka Pelajar.

Atmakusumah. 1982. Tahta Untuk Rakyat, Celah-celah Kehidupan Sultan Hamengku Buwono IX. Jakarta : PT. Gramedia Pustaka Utama.

Budimansyah, Dasim. 2008. Pembelajaran Pembudayaan Nilai Pancasila. Bandung: PT. Genesindo.

Budimansyah, Dasim. 2010. Penguatan Pendidikan Kewarganegaraan Untuk Membangun Karakter Bangsa. Bandung: Widya Aksara Press.

Budimansyah, Dasim. 2012. Perancangan Pembelajaran Berbasis Karakter. Bandung: Widya Aksara Press.

Elmubarok, Zaim. 2008. Membumikan Pendidikan Nilai. Bandung: Alfabeta.

Endarswara, Suwardi. 2010. Etika Hidup Orang Jawa Pedoman Beretika dalam Menjalani Kehidupan Sehari-Hari. Yogyakarta: Narasi.

Hasan, Hamid S. 1996. Pendidikan Ilmu-Ilmu Sosial. Bandung: Jurusan Sejarah Fcivic Education IKIP Bandung.

Hasan, Hamid S. 2000. Multikulturalisme Untuk Penyempurnaan Kurikulum Nasional, Jurnal Pendidkan dan Kebudayaaan. 
Inject, Interdisciplinary Journal of Communication, Vol. 1, No. 2, Desember 2016:145-164

Haviland, William A. 1999. Antropologi. Edisi keempat, Jilid I. Jakarta: Penerbit Erlangga.

Joyce, Bruce., Marsha Weil, Emily Calhoun. 2009. Models of Teaching. (Terjemahan Achmad F dan Ateilla M.), Yogyakarta: Pustaka Pelajar.

Kesuma, Dharma. dkk. 2012. Pendidikan Karakter Kajian Teori dan Praktik di Sekolah. Bandung: PT Remaja Rosdakarya.

Lickona, Thomas. 2013. Pendidikan Karakter Panduan Lengkap Mendidik Mahasiswa Menjadi Pintar dan Baik. Bandung: Penerbit Nusa Media. (Penerjemah: Lita S dari karya Thomas Lickona, Educating for Character. New York: Bantam Book, 2008).

Maftuh, Bunyamin. 2008. Pendidikan Resolusi Konflik, Membangun Generasi muda yang Mampu menyelesaikan Konflik Secara Damai. Bandung: Prodi Kewarganegaraan Sekolah Pascasarjanan UPI.

Maryani, Enok. 2011. Pengembangan Program Pembelajaran Civic Education Untuk Peningkatan Keterampilan Sosial. Bandung: Alfabeta.

Megawangi, Ratna. 2004. Pendidikan Karakter; Solusi yang Tepat untuk Membangun Bangsa. Bogor: Indonesia Heritage Foundation.

Salman, Abdul Malik. 1993. al-Tasamuh Tijâh al-Aqaliyyat ka Dharuratin li al-Nahdhah. Kairo: The International Institute of Islamic Thought.

Sugiyono. 2008. Metode Penelitian Kuantitatif Kualitatifdan R\&D. Bandung: Alfabeta.

Sumaatmadja, Nursid. 2005. Konsep Dasar Civic Education. Jakarta: Pusat Penerbitan Universitas Terbuka.

Supardan, Dadang. 2009. Pengantar Ilmu Sosial, Sebuah kajian Pendekatan Struktural. Jakarta: PT. Bumi Aksara.

Wiriaatmadja, Rochiati. 2007. Metode Penelitian Tindakan kelas. Bandung: PT. Remaja Rosdakarya.

Wiriaatmadja, Rochiati. 2014. Buku Ajar Filsafat Ilmu (Relevansinya Dengan Pendidikan Civic Education. Program Studi Pendidikan Civic Education Jenjang Studi S2 dan S3. Sekolah Pascasarjana UPI.

Wiyani, Novan Ardy. 2013. Membumikan Pendidikan Karakter di SD. Yogyakarta: ArRuzz Media. 